\title{
Sex in the Shadow of the Law: Regulating Sex Work and Human Trafficking in Singapore
}

\author{
Ben CHAPMAN-SCHMIDT* \\ Australian National University College of Arts and Social Sciences, Australia \\ ben.chapman-schmidt@anu.edu.au
}

\begin{abstract}
This paper uses Singapore as a case study in how the international anti-trafficking movement has influenced the regulation of sex work. In doing this, it explores the various historical, geographical, and socio-legal factors which have shaped Singapore's system of regulation. It then presents the contemporary composition of the regulation of sex work in Singapore: a system of informal rules and protections hidden in the shadow of formal legal institutions. Finally, it analyses the impact of the international anti-trafficking movement, with specific emphasis on the American Trafficking in Persons Report, on Singapore's regulation of sex work. It suggests that the recent increase of police raids on red light districts is aimed primarily at image control, and that these raids are undermining a functioning regulatory system. It concludes by suggesting that to improve upon its existing regulatory system, Singapore should focus on eliminating sex worker stigma and improving the rights of migrant workers.
\end{abstract}

The regulation of sex work is an area of public policy subject to an unusual array of international forces. On the one hand, sex workers themselves are often migrants, and the combination of their foreignness and their sexuality, along with the spectre of the diseases (real or imagined) they might carry, can spur policies of restrictive regulation. On the other hand, there has been considerable concern at the international level in the past two decades about sex workers as potential victims of human trafficking, and this concern has in turn sparked transnational efforts to influence domestic regulation. To explore this phenomenon, this paper uses Singapore, a city-state with a significant migrant sex worker population, as a case study in how international influences can shape the regulation of sex work. In particular, it focusses on the influence of the US Trafficking in Persons Report (TIP Report) on Singapore's regulation of sex work.

Singapore's sex industry has a long history and it has come to include an assortment of businesses that range from traditional brothels to escorts and karaoke television (KTV) hostesses - who might reject being labelled as prostitutes, even while deriving

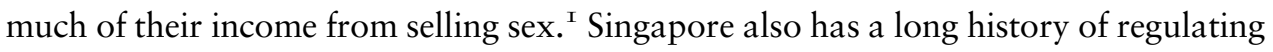

\footnotetext{
* Ph.D. Scholar, School of Sociology, Australian National University College of Arts and Social Sciences.

I. Gerrie LIM, Invisible Trade (Singapore: Monsoon Books, 2004).
} 
prostitution with policies that have oscillated between a tolerationist system and a system of legalised prostitution. ${ }^{2}$ Interestingly, Singapore has maintained a permissive attitude towards sex work despite showing little compunction otherwise about using legislation to enforce traditional morality; consensual sexual intercourse between men, for example, remains illegal. ${ }^{3}$ However, since $20 \mathrm{I} 2$ there has been a marked increase in the frequency of police raids on brothels, including those in the informally designated red-light districts where a special police task force maintains an extra-legal regulatory system. Not coincidentally, after years of criticism, the influential TIP Report has in recent years begun praising Singapore's efforts to reduce the demand for sex work.

This paper thus examines both the nature of the regulatory framework surrounding the sex industry in Singapore and the manner in which this framework has been influenced by international actors. The first half focusses on the regulation of sex work in Singapore by exploring the history of this regulation and the international forces that shaped it, then by explaining the current shape of the regulatory system, and finally by looking at the state of unregulated sex work in Singapore. The second half focusses on the influence of the TIP Report by looking at the structure of the report itself, how it has rated Singapore over the years, and how Singapore has responded to the report. The paper illustrates how Singapore's current policy of increased police raids is based on a desire for image control, and suggests that these raids are undermining a functioning regulatory system. It concludes by offering suggestions for alternative policy options.

\section{SEX WORK IN SINGAPORE}

\section{A. A History of Sex Work in Singapore}

Even at its founding in I 8 I9, Singapore was already developing a sizeable population of migrant sex workers. In its most basic form, this can be explained through the mechanisms of supply and demand. Singapore's colonial government was importing a significant supply of male foreign labour, particularly from China. This quickly led to a highly lopsided sex ratio, ${ }^{4}$ which in turn resulted in a high demand for sexual labour. At the same time, extreme local conditions of poverty in rural Japan and China led to an influx of outbound migrant workers from these countries. ${ }^{5}$ Familial patriarchal institutions putting pressure on young women to "sacrifice" themselves for the good of the family - or in Japan's case, for the good of their nation, which needed remittances of foreign currency to finance its modernisation - meant that there was also a

2. Jean D’CUNHA, "Prostitution Laws: Ideological Dimensions and Enforcement Practices" (I992) 27:I7 Economic and Political Weekly WS 34 .

3. Penal Code (Cap 224, 2008 Rev. Ed. Sing.), s. 377A.

4. Ong puts the highest ratio of males to females at 5.I8:I in I836, while Warren gives a high of I4:I in I 860. Jin Hui ONG, "Singapore" in Nanette J. DAVIS, ed., Prostitution: An International Handbook on Trends, Problems, and Policies (Westport, CT: Greenwood Press, I993), 243 at 269; James Francis WARREN, $A b \mathrm{Ku}$ and Karayuki-san: Prostitution in Singapore, I870-1940 (Singapore: Oxford University Press, I993) at 34 [Warren, Prostitution in Singapore].

5. Warren, Prostitution in Singapore, supra note 4 at 25-35; Lenore MANDERSON, "Migration, Prostitution and Medical Surveillance in Early Twentieth-Century Malaya" in Lara MARKS and Michael WORBOYS, eds., Migrants, Minorities and Health: Historical and Contemporary Studies (New York: Routledge, 2002), 49 at 54. 
significant potential supply of sex workers willing to migrate within East Asia. ${ }^{6}$ Finally, in response to this increase in the supply of unskilled female migrants and the demand for sex work in Singapore, networks were created, often by "secret societies" (organised criminal groups), to facilitate and profit from the migration of potential sex workers to Singapore. ${ }^{7}$

As a British colony, Singapore's policy response to this influx of migrant sex workers was less influenced by international forces than it was simply imported wholesale. Britain passed three Contagious Disease Acts (CDAs) between I 863 and I 869, which aimed to control the spread of sexually transmitted infections (STIs) by licensing brothels, registering the women working there, and requiring sex workers to take frequent health checks. ${ }^{8}$ Singapore in turn passed its own Contagious Disease Ordinance (CDO) in $\mathrm{I} 870$. The $\mathrm{CDO}$ established two designated red-light districts (DRAs): one for Chinese workers and clients, and one for non-Chinese workers and clients. Public brothels, both inside and outside of the DRAs, were registered under the $\mathrm{CDO}$ and subject to periodic inspections, with the women working in these brothels compelled to undertake regular medical examinations. ${ }^{9}$

However, these policies were subsequently challenged by early British feminists, who argued that the CDAs were predicated on a sexual double standard whereby men were permitted sexually licentious behaviour but women were required to keep themselves "pure" or else submit to the State's formal control. This sentiment, combined with the State's indiscriminate targeting and heavy hand in enforcing the regulations, birthed a movement to repeal the CDA, with Josephine Butler emerging as the "moral and charismatic leader of the crusade." ${ }^{\circ}$ Butler argued that prostitution, legitimised by the CDA, amounted to the slavery of women and that it should be abolished. ${ }^{\text {II }}$ Transforming the anti-CDA movement into an abolitionist movement gave it enough political traction that by $\mathrm{I} 886$ the CDA had been fully repealed. ${ }^{\mathrm{I}}{ }^{2}$

It is at this point that a schism emerges between policy goals in Singapore and those of its colonial power, and that we begin to see the impact of international forces on domestic policy making decisions. In Singapore, the principal policy maker and regulator in areas related to sex work was the Chinese Protectorate, which had been formed in 1877 in part to combat instances of sexual slavery. There was particular concern over reports of Japanese girls as young as eleven being sold to procurers for

6. Warren, Prostitution in Singapore, supra note 4 at 25-35; Maria JASCHOK and Suzanne MIERS, "Introduction" in Maria JASCHOK and Suzanne MIERS, eds., Women and Chinese Patriarchy: Submission, Servitude and Escape (London: Zed Books, I994), I; Nina Glick SCHILLER, Linda BASCH, and Cristina BLANC-SZANTON, "Transnationalism: A New Analytic Framework for Understanding Migration" (I992) 645:I Annals of the New York Academy of Sciences I.

7. Ong, supra note 4 at 245 .

8. Judith R. WALKOWITZ, Prostitution and Victorian Society: Women, Class, and the State (Cambridge: Cambridge University Press, I982) at II-69.

9. James Francis WARREN, "Prostitution and the Politics of Venereal Disease: Singapore, I 870-98" (I990) 2I:2 Journal of Southeast Asian Studies 360 [Warren, "Prostitution and Politics"]; Warren, Prostitution in Singapore, supra note 4 at 38.

Io. Walkowitz, supra note 8 at 70, 93 .

II. Kathleen BARRY, Female Sexual Slavery (New York: NYU Press, I979) at I4-I6.

I2. Walkowitz, supra note 8 at 70, 90-99. 
Singaporean brothels by starving parents, ${ }^{\mathrm{I} 3}$ along with stories of women sold into debt bondage in Shanghai being shipped to Singapore by way of Hong Kong. ${ }^{\mathrm{I}}{ }^{\mathrm{T}}$ The first Protector, William A. Pickering, acted to stop what would be described today as human trafficking ${ }^{5}$ for both labour exploitation and sexual exploitation. ${ }^{16}$ As part of this fight, Pickering developed a stringent system of brothel registration under the CDO which was designed both to stop the spread of STIs and to help him locate and liberate women and girls trapped in sexual bondage. ${ }^{\mathrm{I}}$

From the Protectorate's perspective, many of the sex workers had chosen the trade of their own free will, and their primary objectives were preventing women from being coerced or deceived into the sex trade, stopping the abuse of sex workers, and controlling the spread of STIs. In this respect they found the CDO to be a very useful tool. However, for the abolitionists, the CDO represented an unacceptable legitimisation of a practice they were trying to eliminate entirely, and thus needed to be repealed. Though local authorities tried to resist international pressure, for example by arguing that a complete repeal of the CDO would lead to a severe outbreak of STIs, Singapore's colonial status meant that the British Secretary of State was able to force the issue and order the CDO repealed in I 887 . Unfortunately, subsequent events illustrate the dangers of international actors overruling local policy makers who have better knowledge of conditions on the ground: by I 896, STI prevalence in Singapore was close to five times that of $\mathrm{I} 884$. $^{\text {I } 8}$

Despite losing the CDO, policy makers in Singapore continued to resist international pressure by pursuing policies predicated on a belief both in the possibility of consensual sex work and the need for the State to regulate that work. For example, in I 896 Singapore passed the Women and Girls' Protection Ordinance, which allowed the Protector to remove sex workers younger than I 6 from brothels and place them in special homes, and also let them search any ship or building where they suspected victims of human trafficking might be held. ${ }^{99}$ At the same time, however, abolitionist feminists were also gaining strength internationally. In Britain, they had been joined by religious puritans to launch a moral crusade against what they called the "White Slave trade." The crusade was built on stories, often sensationalised or fictional, of young, innocent Caucasian girls who were tricked or coerced into sexual slavery. The focus on the youth and innocence of white victims meant that sex workers who were less young, innocent, or white were no longer

\footnotetext{
13. Warren, Prostitution in Singapore, supra note 4 at 32, 67-70.

I4. Gail HERSHATTER, "The Hierarchy of Shanghai Prostitution, I 870-I949" (I989) I 5:4 Modern China 463 at $476-477$.

I 5. Based on the definition of human trafficking given in UN General Assembly, Protocol to Prevent, Suppress and Punish Trafficking in Persons, Especially Women and Children, Supplementing the United Nations Convention against Transnational Organized Crime, GA Res. 55/67, UN Doc A/55/PV.8I (2000). Note that different actors use different definitions of human trafficking, making any discussion of it as a coherent phenomenon problematic.

I6. Ng Siew YOONG, "The Chinese Protectorate in Singapore, I 877-I900” (I96I) 2:I Journal of Southeast Asian History 76.

I7. Warren, "Prostitution and Politics", supra note 9 at 366-370.

I8. Ibid.

I9. Yoong, supra note 16 at 88.
} 
perceived as victims. ${ }^{20}$ This led to the passage of the 1885 Criminal Law Amendment Act, which despite nominally targeting "white slavers" was primarily used to shut down brothels and prosecute sex workers. ${ }^{2 I}$ The abolitionist movement, originally predicated on improving the welfare of women, had now turned against certain classes of women.

After taking hold in Britain, the moral crusade against White Slavery went global. In I904, the League of Nations passed a Convention against White Slavery, which sought to "suppress the 'criminal traffic' of women or girls compulsively procured for 'immoral purposes.'" 22 Though largely toothless in and of itself, the Convention gave leverage to abolitionists to push for domestic legislation. In some cases, this legislation was used similarly to Britain's in persecuting marginalised individuals; in the United States, for example, the Mann Act of I9IO was used by police primarily to arrest sex workers and persecute men of colour. In other cases, the legislation was used to restrict the mobility of women, with Greece, for example, passing legislation in I9 2 that banned women under twenty-one from travelling abroad without a permit. ${ }^{23}$

The fight against White Slavery first arrived in its full form in Singapore in I9I 2 as the result of the publication of The White Slave Market by Mrs. Archibald MacKirdy and W.N. Willis. ${ }^{24}$ Though the book claimed to be an accurate account of the conditions faced by European sex workers on Malay Street in Singapore, it was, like many of the stories of the White Slave trade, built on exaggerations and outright fictions. Willis, a confidence artist from Australia, grossly exaggerated the number of brothels on Malay Street and gave a staggering (and false) ninety-percent rate of STI prevalence among the European sex workers there. Nevertheless, this book proved wildly popular and sparked an outrage amongst the British abolitionists. In an attempt to stave off the broader abolitionist effort, Singaporean authorities cracked down on European prostitutes with the passage of a new Women and Girls' Protection Ordinance in I9I3, which allowed authorities to banish or imprison European pimps and led to European sex workers fleeing for other parts of Asia. By I9I 6 there were no longer any known European sex workers in Singapore. ${ }^{25}$

The next round of international pressure came from Japan, after the increasinglyimage conscious government in Tokyo began to worry that the ubiquitous presence of Japanese migrant sex workers in major international cities was making Japan look backwards and impoverished. As a result, in I9I9 the Imperial government ordered its

20. Frederick K GRITTNER, White Slavery: Myth, Ideology, and American Law (New York: Garland Publishing, Inc., I990); Mary Ann IRWIN, “White Slavery' as Metaphor Anatomy of a Moral Panic” (I996) 5, online: Ex Post Facto <http://www.walnet.org/csis/papers/irwin-wslavery.html>; Jo DOEZEMA, "Loose Women or Lost Women? The Re-Emergence of the Myth of White Slavery in Contemporary Discourses of Trafficking in Women" (I999) I 8: I Gender Issues 23; Barry, supra note I I at 27-32.

2I. Walkowitz, supra note 8 at 2I I-252.

22. Anne T. GALLAGHER, The International Law of Human Trafficking (New York: Cambridge University Press, 20I0) at I 3 [Gallagher, Law of Trafficking].

23. Doezema, supra note 20 at 30.

24. Apparently Willis provided the material on Singapore, MacKirdy the feminist rhetoric that framed it. MacKirdy's given name does not appear to be given anywhere.

25. Warren, Prostitution in Singapore, supra note 4 at I 53-I 55. 
consuls to encourage and assist the return of overseas sex workers to Japan, nominally under the aegis of the global abolitionist movement. The following year, the Japanese consul in Singapore worked with local authorities to forcibly repatriate all of the Japanese sex workers in Singapore. Unfortunately, the Japanese State's interest in these migrants ended with their repatriation, and once home they faced ostracism, discrimination, and a general lack of opportunities. ${ }^{26}$

These two concessions to international pressure initially had a relatively minor impact on the overall nature of the sex industry in Singapore, which was composed largely of Chinese sex workers. However, they appear to have provided both the ideological framework and policy precedents to empower Singapore's nascent domestic abolitionist movement. This movement built on those concessions to pressure Singapore first into closing its borders to migrant sex workers entirely in 1927, and then into amending the Women and Girls' Protection Ordinance to make brothels illegal in I930. This forced brothels to move underground, though the police, still operating under the ideological assumptions of the old Chinese protectorate, focused on containing them in now-unofficial DRAs rather than fully enforcing this provision. ${ }^{27}$

Though the moral crusade against the White Slave Trade had largely faded by the middle of the 20 th century, ${ }^{28}$ by this point the abolitionist movement had already become a localised phenomenon in Singapore. The movement reached its peak when the People's Action Party, after their electoral victory in 1959, responded to the political demands of women's groups and religious organisations by launching a campaign for the elimination of "yellow culture" (vice) in Singapore. ${ }^{29}$ This included police raids on brothels, the results of which were by any measure disastrous. The brothels moved out of the unofficial DRAs, where they had been easy to find, and into residential areas, where they could be more easily disguised as something else. Sex workers, who could no longer operate as openly, became more reliant on pimps and individual customers and thus more vulnerable to exploitation from both. The secret societies that Pickering had struggled to remove from the sex industry also came back in force. Moreover, after an initial decline, the total number of brothels in Singapore appears to have actually increased. ${ }^{30}$

With backlash building to the negative externalities of the anti-yellow culture campaign, the government decided to return to a policy of regulation and geographic concentration. Brothel owners were told discreetly that if they left the residential areas and returned to the DRAs they would not be harassed anymore, a move which marked the advent of the current system of extra-legal regulation of sex work in Singapore. ${ }^{3 \mathrm{I}}$

26. Ibid. at I 59-I77.

27. Ong, supra note 4 at 246.

28. The last two major international agreements, the International Convention for the Suppression of the Traffic in Women and Children and the International Convention for the Suppression of the Traffic in Women of Full Age, were passed in I92 I and 1933 respectively. See Gallagher, Law of Trafficking, supra note 22 at $\mathrm{I} 4$.

29. Ng Hui HSIEN, Moral Order Underground: An Ethnography of the Geylang Sex Trade (Masters Thesis, National University of Singapore, 20I I) at 40 [unpublished].

30. Ong, supra note 4 at 247.

3I. Hsien, supra note 29 at 40. 
The failure of the anti-yellow culture campaign and its subsequent reversal were understood to reflect the broader failure of the abolitionist movement, imported from abroad, to provide a workable framework for dealing with sex work in a way that matched government priorities, the will of the people or the needs of sex workers themselves. And thus, in searching for alternative policy frameworks, authorities returned to a system very similar to the last system that had worked for them: the CDO.

\section{B. Extra-Legal Regulated Sex Work}

One the most interesting characteristics of Singapore's current regulation of sex work is that it is conducted through a largely extra-legal framework - a regulatory framework that does not have any official legal sanction. This is because the laws in Singapore regarding sex work largely remain as impermissive as they were during the anti-yellow culture campaign. The purchase of heterosexual ${ }^{32}$ sex itself is legal, but all the practices necessary to facilitate it are not. Soliciting or even loitering by sex workers is forbidden by the Miscellaneous Offences (Public Order and Nuisance) Act. ${ }^{33}$ The Women's Charter forbids running brothels and allows the State to take sex workers under 2 I into protective custody. ${ }^{34}$ The Penal Code forbids importing female minors under I 8 for prostitution and commercial sex (prior to 2007 , this provision applied only to minors under I 6). ${ }^{35}$ Furthermore, the Immigration Act both prohibits prostitutes from entering Singapore and allows for their deportation. ${ }^{36}$ Given these provisions, an individual can only perform sex work in Singapore provided they are above $2 \mathrm{I}$, not an immigrant, don't act indecent, solicit or even loiter in public, and don't work in a brothel or have any sort of manager. In other words, sex work in Singapore is functionally impossible without breaking the law.

Keeping these laws in place allows Singapore to point to the Women's Charter and claim that brothels are illegal; these claims can be used to placate domestic and international critics in the abolitionist movement. However, those statutes in no way accurately describe the actual regulation of the sex industry, which is conducted through an informal extra-legal agreement between law enforcement, sex workers and brothel owners. The system was originally created by the Anti-Vice Enforcement Unit (AVEU) in cooperation with other agencies, ${ }^{37}$ though it has since been replaced by a specialised taskforce in the Criminal Investigation Department (CID).$^{38}$

The first and in many ways most obvious feature of Singapore's extra-legal system of regulation is the geographic isolation and containment of brothels. Brothels are permitted by the CID taskforce in four DRAs: Geylang, Flanders Square, Keong Saik Street, and Desker Road. However, these zones are the result of historic fact (they are

\footnotetext{
32. Any sex between men, as already mentioned, is illegal in Singapore. Sex between women, financially compensated or otherwise, is not, though women are forbidden from entering the state-sanctioned brothels. See ibid. at 45 . Miscellaneous Offences (Public Order and Nuisance) Act (Cap I 84, I997 Rev. Ed. Sing.), s. I9. 
where brothels have traditionally been located) and police policy (a deliberate decision not to shut down brothels in these areas following the failed anti-yellow culture campaign), rather than any official policy or zoning code. As a result, these DRAs can be easily shut-down without any formal changes in policy. The previous DRA in Johore Road, populated largely by transgender sex workers, was destroyed by fires in I990 and I99I, and in the rebuilding process its status as a DRA appears to have evaporated. Another former DRA in Tanjong Pagar was instead deliberately targeted for urban redevelopment, which was accompanied by an end to police toleration of brothels in this area. ${ }^{39}$ This geographic isolation reflects the strong role that stigma continues to play in the regulation of sex work - because the general population does not want "immoral" activities occurring in proximity to where they live, the State tries to contain these activities in certain prescribed zones.

In addition to delineating where brothels can operate, Singapore's extra-legal system regulates how they can operate. Men wishing to open a brothel (and it does seem to be all men running these brothels) must apply in person with the taskforce. Potential brothel owners must go through a background check to ensure they do not have a criminal record related to prostitution and are not connected to any secret societies; if their "application" is successful, the unofficial rules they are required to follow are read out loud for them to memorise. ${ }^{40}$ Brothel owners are also permitted to own only one brothel (to prevent big businesses from forming within the sex industry) and they can only employ women who are also registered with the taskforce. Checks are conducted by the taskforce in cooperation with other units and if violations are discovered, brothels can be closed temporarily or shut down by administrative fiat without resorting to the courts. Brothel owners accept these shut-down orders because the alternative is prosecution under the Women's Charter and possibly the Penal Code, both of which call for strict penalties. ${ }^{4 \mathrm{I}}$

Sex workers looking to work in one of the "sanctioned" brothels must also register with the task force. As part of this registration, the task force interviews a potential worker to ensure that she (these sex workers are exclusively female) is at least eighteen years of age, that she is registering voluntarily and that she understands the relevant health concerns, before recording her personal details. ${ }^{42}$ The last step of the sex worker's registration is entry into the Medical Surveillance Scheme (MSS), which is run by the Department of STI Control of the Ministry of Health. If the sex worker tests negative for STIs, ${ }^{43}$ she is issued with a special yellow health card. Though these yellow cards have no special legal status, they are unique to sex workers. Sex workers in the MSS are required to attend regular STI screenings at either the single public STI clinic or a designated general practice clinic. If an STI is detected they are given immediate

39. David BRAZIL, No Money, No Honey! (Singapore: Angsana Books, I994). Singaporeans I have spoken with linked the destruction of the Tanjong Pagar DRA to its presence within the district represented by Singapore's former Prime Minister Lee Kuan Yew.

40. Hsien, supra note 29 at $40-44$.

4I. Ong, supra note 4 at 248-249.

42. Yang Joel WONG, "Brothels, Pimps and Prostitutes: The Administration of Criminal Justice vis-a-vis Prostitution" (I996) I 7 Singapore Law Review I 54 at I70 [Wong, "Brothels, Pimps and Prostitutes"].

43. Tested STIs are gonorrhoea, chlamydia, HIV, and syphilis; HPV, as far as I can tell, is not a bar to sex work. 
medical assistance, though they must surrender their cards and stop working until they test negative again. ${ }^{44}$

The interview with the task force reflects the same concerns about consent that had preoccupied the Chinese Protectorate in the I9th century, with the CID seeking to ensure that all sex workers are entering the industry consensually and are mature and knowledgeable enough to give informed consent. Likewise the MSS has some obvious elements of continuity from the $\mathrm{CDO}$, though given the long time lapse between the two measures it is probably not enough to credit history alone with the creation of such a comprehensive scheme. The Singaporean State has shown a general willingness to paternalistically involve itself in the private lives of its citizens and visitors, not only by forbidding sex between men and pregnancy for migrant workers, but also, for example, through a variety of schemes to encourage Singaporean couples to conceive. ${ }^{45}$ As such, the application of bio-power and surveillance to control the workings of the sex industry can be understood as another service provision by the State, built upon gendered and heteronormative assumptions about the needs and desires of its citizens. ${ }^{46}$

Most of the sex workers in the MSS come from abroad, particularly from Thailand, Malaysia, and China. This is likely due in part to the significant stigma associated with sex work and Singapore's general reliance on a migrant workforce for work considered dirty or unpleasant - domestic work and construction are likewise dominated by migrant workers. It may also reflect the preferences and available income of Singapore's male migrant workers, who also largely come from Thailand, Malaysia, and China (as well as South Asia). Regardless of the reason, however, it is possible for migrant women to work within Singapore's extra-legal regulatory system. To do so they must apply for a social visit pass to Singapore with the owner of the brothel they intend to work for as their local sponsor. If potential migrants do not have contact with Singaporean brothels, they can work through agents; in these cases, brothel owners are required to provide the names of agents to the CID, who can thus monitor transnational networks associated with the sex trade. ${ }^{47}$

If their application is successful, migrant women can work in Singapore subject to the same conditions as Singaporean sex workers, with two notable exceptions.

44. Mee-Lian WONG, Roy CHAN, and David KOH, "A Sustainable Behavioral Intervention to Increase Condom Use and Reduce Gonorrhea among Sex Workers in Singapore: 2-Year Follow-Up” (r998) 27:6 Preventive Medicine 89I; Mee-Lian WONG et al., "Sex Work and Risky Sexual Behaviors among Foreign Entertainment Workers in Urban Singapore: Findings from Mystery Client Survey" (20I 2) 89:6 Journal of Urban Health I03 I; Ong, supra note 4 at $25 \mathrm{I}$.

45. Joshua E. KEATING, “The Bedroom State" Foreign Policy (June 20I2), online: Foreign Policy <http://www.foreignpolicy.com/articles/201 2/04/23/the_bedroom_state?page=0,2 >; Robin Grier, "A Singaporean Strategy for Increasing the Fertility Rate" Cherokee Gothic (26 April 20I3), online: Cherokee Gothic <http://cherokeegothic.com/2013/o4/26/a-singaporean-strategy-for-increasing-thefertility-rate/>; Agence France Presse, "Singapore Offers Love Vouchers to Promote Dating" NY Daily News (I7 December 20I2), online: NY Daily News <http://www.nydailynews.com/life-style/singaporeoffers-love-vouchers-promote-dating-article-I.I222047 $>$.

46. Michel FOUCAULT, The History of Sexuality (New York: Pantheon Books, I978) at I33-160; Michel FOUCAULT, The Birth of Biopolitics: Lectures at the Collège de France, 1978-1979 (New York: Picador, 20I0); Evelyne MICOLLIER, "Social Significance of Commercial Sex Work: Implicitly Shaping a Sexual Culture" in Evelyne MICOLLIER, ed., Sexual Cultures in East Asia: The Social Construction of Sexuality and Sexual Risk in a Time of AIDS (New York: Routledge, 2003), 3.

47. Hsien, supra note 29 at 37-42. 
The first is that they are more vulnerable to state sanctions, since if a migrant sex worker fails to comply with the health requirements or commits a crime, they can be deported and barred from re-entry. ${ }^{4}$ The second is that the nature of these social visit passes is such that these migrants can only stay for short periods before needing to leave and apply for re-entry. As such, the brothels have more power over migrant workers, since if a brothel declines to sponsor a migrant's readmission then she will no longer be able to enter the country. The only way a migrant worker can stay in Singapore legally in the long term is to marry a Singaporean. Interestingly, Singapore has worked hard to prevent other categories of migrant workers from obtaining permanent residency this way, for example by attaching conditions to work permits that forbid marrying Singaporeans or becoming pregnant. ${ }^{49}$ In the case of migrant sex workers, the assumption may be that sex worker stigma is sufficient to prevent such marriages.

\section{Unregulated Sex Work}

There are a number of reasons sex workers might choose to work outside of the DRAs, and thus be outside of the extra-legal system of the MSS. They might be looking for a better price - clients can be more exclusive outside of the DRAs, and sex workers can potentially earn more either as freelancers or working for semi-permanent brothels that shift in response to pressure from the taskforce. They might be too young to register for the MSS, for while there is virtually no child (here meaning specifically prepubescent) prostitution in Singapore, there are a number of sixteen- and seventeen-year-old sex workers working part-time in bars, massage parlours, escort services, and unisex hair salons. They might be male or transgender, and thus excluded by their own bodies from the MSS. However, the most significant group of sex workers not in the MSS are migrant women unable or unwilling to enter through the channel provided by the extra-legal framework.

This latter group includes migrants who have previously been deported and are thus barred from re-entry, who lack the proper connections, who are not aware of the semi-official channels for entry, who are underage, who want to make more money than they can in the DRAs, or who simply want more autonomy than that afforded by brothel work in the MSS. Even migrants willing to enter the MSS and who are not categorically barred may still be denied entry, however, because the taskforce enforces an unofficial quota on the number of migrant sex workers, and the demand for entry far exceeds the cap. Regardless of the reason, however, all of these migrants are forced to look for alternative methods for getting into Singapore. ${ }^{50}$ Migrant sex workers not registered with brothels still tend to attempt entry into Singapore on Social Visit Passes. However if the Immigration and Checkpoint Authority (ICA) suspects they intend to engage in sex work while in Singapore they will be denied entry and forced to return home at their own expense. Because of this risk many migrant sex workers, particularly

\footnotetext{
48. Ong, supra note 4 at 254 .

49. Brenda S. A. YEOH and Shirlena HUANG, "Sexualised Politics of Proximities among Female Transnational Migrants in Singapore” (2010) I6:I Population, Space and Place 37.

50. Hsien, supra note 29 at 48 ; Ong, supra note 4 at $249-256$.
} 
those with no prior experience in Singapore, purchase the services of migration brokers to facilitate their entry into the country. ${ }^{5 \mathrm{I}}$

Another category of migrant sex workers outside of the MSS are women who have been lured into the country under false pretences. These are often women who have been offered work as a domestic helper and given a work pass from the Ministry of Manpower (MOM), but who, upon their arrival, discover they are actually expected to work as entertainers at a KTV or hostess bar - positions which can include an expected component of sex work. There is a process for lodging a complaint against a deceptive employer with the MOM, but while their cases are being investigated the MOM withholds their passports and issues them with special "White Passes". Migrants with these passes are forbidden from finding other work, and while the MOM can find them temporary jobs, the positions are few, the waitlist long and the pay low. When the case is closed (one way or the other) the woman's passport is returned and she is sent to her home country. Because this puts migrant women in a difficult financial situation, many White Pass-holders ultimately find that sex work is the only means they have to support themselves anyway. ${ }^{52}$

Being outside the extra-legal system brings with it attendant risks. A report on STI rates for sex workers notes that there was a 20.7 percent STI infection rate among a random sample of arrested foreign female sex workers, compared with an infection rate of less than five percent among MSS sex workers. ${ }^{53}$ Migrant workers are also highly dependent on their agents, with the result that some of them, despite willingly migrating for sex work, wind up in conditions of exploitation including heavy debts, agents taking significant portions of their wages, lack of freedom of movement, or lack of control over their clients or condom use. ${ }^{54}$ However, even if they were willing or able to file a criminal complaint against these agents, their illegal status makes it difficult for them to go the police, since this could result in their own deportation. Being deported prematurely, either by going to the police or by being caught in a raid, can result in the migrant going home before she has had a chance to make back her initial expenses, saddling her with a significant debt burden. ${ }^{55}$

Unregulated sex work thus runs counter to two main policy goals for the regulation of sex work in Singapore: preserving public health and guaranteeing consent. As such, we might ask why the State does not do more to bring these sex workers into its regulatory framework instead of trying futilely to keep them out or expel them. Part of the answer is no doubt related to sex work stigma: the discursive construction of sex workers as morally transgressive and vectors for disease. ${ }^{56}$ This stigma is the reason the

5I. Nicolas LAINEZ, A Foot In and Foot Out: Sex Migration of Vietnamese Women to Singapore, Research Report No. 3 (Ho Chi Minh City: Alliance Anti-Trafic, 20I I).

52. Hsien, supra note 29 at 70, 90-91.

53. Wong et al., supra note 44. Note that this rate is reflective of sex workers who are more likely to be targeted with arrest - sex workers who are potentially both more marginalised and more risk-prone.

54. See for example Sallie YEA, “'Shades of Grey': Spaces in and beyond Trafficking for Thai Women Involved in Commercial Sexual Labour in Sydney and Singapore” (2012) I9:I Gender, Place and Culture 42.

55. Lainez, supra note $5 \mathrm{I}$.

56. Carol LEIGH, "Inventing Sex Work" in Jill NAGLE, ed., Whores and Other Feminists (New York: Routledge, I997), 223 at 225; Graham SCAMBLER, "Sex Work Stigma: Opportunist Migrants in London” (2007) 4I:6 Sociology I079. 
task force both tries to contain sex workers within the DRAs and imposes an unofficial quota on the number of migrant sex workers permitted entry. Even with these restrictions, many Singaporeans still worry that the migrants they do associate with might be engaging in sex work. For example, when newspapers began suggesting that Filipino domestic helpers were supplementing their meagre incomes with sex work on the weekends, Singaporean families responded by further restricting the freedom of their domestic helpers; and when reports came out that Chinese "study mothers" 57 were engaging in sex work, the government responded by limiting their employment options. ${ }^{5}$ However, it is possible that the biggest obstacle to expanding this regulatory system has been the ongoing international campaign against human trafficking, and in particular the American Trafficking in Persons Report.

\section{SINGAPORE AND THE TIP REPORT}

\section{A. The Trafficking in Persons Report}

During the past twenty years, there has been an increasing focus internationally on human trafficking, and in particular human trafficking for the purpose of sexual exploitation. This has led to the creation of various international and regional agreements and legal instruments with the stated purpose of ending human trafficking. The most significant of these from an international law perspective is the the Protocol to Prevent, Suppress and Punish Trafficking in Persons, especially Women and Children (The Palermo Protocol), which was signed in 2000 as part of the United Nations Convention against Transnational Organized Crime. ${ }^{59}$ However, in terms of its influence on policy decisions in Singapore (and, arguably, internationally), the most important legal instrument has been the American Trafficking Victims Protection Act (TVPA, also of 2000) and its accompanying Trafficking in Persons Report (TIP Report). ${ }^{60}$

The TVPA's greater influence is a result of its superior incentive structure: while signing the Palermo Protocol is voluntary and there are no sanctions applied to noncompliant parties, the TVPA threatens to punish any state whose anti-trafficking efforts the US judges to be insufficient. ${ }^{6 \mathrm{I}}$ In practice, this means that the US Department of State classifies countries into four tiers in its annual TIP Report: Tier I, for governments complying with the TVPA's minimum standards; Tier 2, for governments making an effort to bring themselves into compliance; Tier 3, for governments that are neither complying nor making an effort to do so; and a Tier 2 Watch List, for governments teetering on the edge of Tier $3 .{ }^{62}$ For countries placed in Tier 3 , the TVPA calls for the

\footnotetext{
57. Women from China on special visas to accompany children or grandchildren coming to Singapore to study.

58. Yeoh and Huang, supra note 49.

59. Gallagher, Law of Trafficking, supra note 22 at 29.

6o. Janie A CHUANG, “The United States as Global Sheriff: Using Unilateral Sanctions to Combat Human Trafficking” (2006) 27:2 Michigan Journal of International Law.

6I. US, HR 3244, Victims of Trafficking and Violence Protection Act of 2000, 106th Cong., 2000 [TVPA].

62. US Department of State, 2013 Trafficking in Persons Report (Washington, DC: US Department of State, 2013) [US Department of State, 2013 TIP Report].
} 
American government to withhold non-humanitarian, non-trade foreign assistance and to oppose assistance being given from multilateral bodies such as the IMF and development banks. A 2008 amendment to the TVPA also requires countries that would have been placed in the Watch List for a third consecutive year to instead be placed in Tier 3. As such, tier placement - in particular the Watch List - can be an effective means of coercing governments into changing their policies.

The threat of these sanctions has arguably pushed countries into taking greater action against human trafficking. ${ }^{63}$ However, these actions are responding to "human trafficking" as defined by the TVPA, a definition whose drafting was and whose interpretation continues to be contested by various actors and associations. Though ideologically diverse in nature, these actors and associations can largely be grouped into two movements: the new abolitionist movement, which includes both radical feminists and conservative religious groups, and the sex workers rights' movement, which can include both pro-sex feminists and migrants' rights groups. The former takes the position that consent is incompatible with sex work; as such, all sex work is human trafficking, and states therefor should fight trafficking by criminalising practises related to sex work and dismantling the sex industry. ${ }^{64}$ The latter takes the opposite stance, arguing that the principal source of violence suffered by migrant sex workers is their marginalised legal status as both migrants and sex workers, and that to protect them their work should be de-criminalised, de-stigmatised and afforded the same legal protections granted to everyone else. ${ }^{65}$

The contested nature of the TVPA is made explicit by its inclusion of two distinct definitions of human trafficking. On the one hand, "sex trafficking" is defined as "the recruitment, harboring, transportation, provision, or obtaining of a person for the purpose of a commercial sex act." ${ }^{66}$ This definition, which ignores the agency of individuals being trafficked, is the one preferred by the abolitionist movement. On the other hand, the TVPA defines "severe forms of trafficking in persons", as "sex trafficking in which a commercial sex act is induced by force, fraud, or coercion, or in which the person induced to perform such act has not attained I 8 years of age” as well as "the recruitment, harboring, transportation, provision, or obtaining of a person for labor or services, through the use of force, fraud, or coercion for the purpose of subjection to involuntary servitude, peonage, debt bondage, or slavery." 67

63. Anne T. GALLAGHER, "Improving the Effectiveness of the International Law of Human Trafficking: A Vision for the Future of the U.S. Trafficking in Persons Reports" (2OII) I 2:3 Human Rights Review 38I [Gallagher, "Improving the Effectiveness of Law"].

64. Ronald WEITZER, "The Social Construction of Sex Trafficking: Ideology and Institutionalization of a Moral Crusade" (2007) 35:3 Politics Society 447.

65. Doezema, supra note 20; Jo BINDMAN and Jo DOEZEMA, Redefining Prostitution as Sex Work on the International Agenda (London: Anti-Slavery International, I997); Selda DAGISTANLI and Sanja MILIVOJEVIC, “Appropriating the Rights of Women: Moral Panics, Victims and Exclusionary Agendas in Domestic and Cross-Borders Sex Crimes" (2013) 40 Women's Studies International Forum 230; Wendy CHAPKIS, "Trafficking, Migration, and the Law: Protecting Innocents, Punishing Immigrants" (2003) I7:6 Gender and Society 923; Kamala KEMPADOO, "Globalizing Sex Worker Rights" in Kamala KEMPADOO and Jo DOEZEMA, eds., Global Sex Workers: Rights, Resistance and Redefinition (New York: Routledge, I998), I.

66. TVPA, supra note 6I, s. I03(9).

67. Ibid., s. I03 $(8)(\mathrm{B})$ 
This definition, which requires force, fraud or coercion (or else being below the age where consent is thought possible) and which recognises non-sexual forms of human trafficking, is the one preferred by the sex workers rights' movement. In theory, the TVPA's minimum standards (and thus the threat of sanctions) are only predicated on measures taken to prevent "severe forms of trafficking" - a win for the sex workers rights' movement. ${ }^{68}$ In practice, however, the application of the law leaves plenty of room for ideological (re)interpretation, and Bush's election in 2000 meant that religious conservative and their abolitionist feminist allies would take over the human trafficking beat at the State Department just in time for the first TIP Report.

\section{B. The TIP Report on Singapore}

In 200I, the first year the report was published, Singapore was placed in Tier 2. Though nominally tier placement is in response to "severe" forms of trafficking only, some of the report's critiques were that "prostitution is not illegal" and "the authorities usually tolerate prostitution, which largely involves foreign women" ${ }^{69}$ - reflections of the strong influence of the abolitionist movement in the writing of the report. In 2002 the report largely repeated itself, ${ }^{70}$ and in 2003 it omitted Singapore entirely, ${ }^{7 \mathrm{I}}$ but in 2004 and again in 2005 Singapore was back in Tier 2, with the report criticising it for not criminalising commercial sex with a minor below I 8 and for allowing Singaporeans to partake in sex tourism..$^{72}$

The initial two reports appear not to have had a major impact on Singapore, but the 2004 report sparked a parliamentary question on Singapore's Tier 2 placement. In response, Minister for Home Affairs Wong Kan Seng said he was "puzzled" by both the ranking and the report's numbers. ${ }^{73}$ Later the Ministry of Home Affairs (MHA) released a brief report rebutting some of the American claims and challenging them to reveal their sources. They also wrote that they felt no need to amend the Penal Code for commercial sex with minors, claiming that "there is no evidence to suggest that persons between $\mathrm{I} 6$ and $\mathrm{I} 8$ years old are as vulnerable as those below the age of $16 . "{ }^{74}$ In contrast to these statements, however, Singapore's actions reflected a more cooperative stance, and in 2006 Singapore was upgraded to Tier I after "parliament approved legislation that, when enacted, will criminalize the offense of child sex tourism committed by Singaporean citizens in other countries and the commercial sexual

68. See generally ibid.

69. US Department of State, 200I Trafficking in Persons Report (Washington, DC: US Department of State, 200I) at 66.

70. US Department of State, 2002 Trafficking in Persons Report (Washington, DC: US Department of State, 2002).

7I. US Department of State, 2003 Trafficking in Persons Report (Washington, DC: US Department of State, 2003).

72. US Department of State, 2004 Trafficking in Persons Report (Washington, DC: US Department of State, 2004); US Department of State, 2005 Trafficking in Persons Report (Washington, DC: US Department of State, 2005).

73. WONG Kan Seng, Question for Written Answer, 20 July 2004, Home Team Speeches (Singapore: Singapore Ministry of Home Affairs, 20 July 2004).

74. Singapore Ministry of Home Affairs, Comments on the 2004 Trafficking in Persons (TIP) Report on Singapore by the United States Department Of State (Singapore, 2004). 
exploitation of persons under the age of 18 , regardless of consent." 75 The influence here of the TIP Report is clear, but given that the Taskforce had already been preventing girls under I 8 from working in sanctioned brothels and that it would only forbid child sex tourism (the report had criticised sex tourism in general), these actions should probably be seen as minor concessions, similar to when Singapore expelled the European sex workers of Malay Street in I9I3.

In 2007, however, Singapore was once more in Tier 2, with the Report noting that the Penal Code had yet to be amended. ${ }^{76}$ That year the MHA released a brief statement saying it was "baffled" by the report, but said nothing further, perhaps believing that the passage of the amendment later that year ${ }^{77}$ would be enough to put them back in the Americans' good graces. It was not. In 2008, Singapore remained in Tier 2, with the report praising the amendment before going on to say, "the government did not prosecute or convict any trafficking offenders during the reporting period, and did not take adequate measures to protect victims of trafficking, particularly foreign domestic workers subjected to forced labor conditions." 78

That year, parliamentary questions were again asked about Singapore's ranking. Minister for Home Affairs Wong Kan Seng vigorously defended the status quo and accused the report of "gross distortion[s] of reality," before observing that, "we cannot obviously 'arrange' for prosecution numbers to go up without evidence or basis just so that we can get a better rating from the U.S. State Department."79 He went on to argue that, "the evidence does not show that sex workers are forced or deceived to work as prostitutes in Singapore. Many indeed come here for economic reasons." 80 This response is particularly interesting given that the government's typical response to questions on sex work has been to point at the law on the books (which largely forbid sex work) while in practice the police and various ministries have cooperated to create a system of extra-legal regulation. It would seem to indicate that even at the highest level, the Singaporean government was rejecting abolitionism.

The next two years saw a number of significant changes to the TIP report. Previously it had been criticised for the poor quality of its data and its lack of transparency, ${ }^{8 \mathrm{I}}$ its focus on sex trafficking to the exclusion of other forms of trafficking, ${ }^{82}$ and for

75. US Department of State, 2006 Trafficking in Persons Report (Washington, DC: US Department of State, 2006) at 222-223.

76. US Department of State, 2007 Trafficking in Persons Report (Washington, DC: US Department of State, 2007) at I 82-I 83 .

77. Penal Code, supra note 3, s. 376B-D.

78. US Department of State, 2008 Trafficking in Persons Report (Washington, DC: US Department of State, 2008).

79. WONG Kan Seng, Written Answer to Parliament Question on What Will Be the Course of Action to Improve Singapore's “Tier 2" Placement, Home Team Speeches (Singapore: Singapore Ministry of Home Affairs, 2008).

8o. Ibid.

8I. US Government Accountability Office, Human Trafficking: Better Data, Strategy, and Reporting Needed to Enhance U.S. Antitrafficking Efforts Abroad, GAO-06-825 (Washington, DC: US Government Accountability Office, 2006).

82. Anne T. GALLAGHER, "Trafficking in Persons Report (review)" (200I) 23:4 Human Rights Quarterly II 35 at II38; Chapkis, supra note 65 at 930. 
punishing countries for not criminalising sex work. ${ }^{83}$ Starting with 2009 , though, critics noted improvements in all of these areas, likely reflecting the change in presidential administrations that year. ${ }^{84} 2010$ saw continued improvements to the TIP Report, as well as the US's inclusion of itself in the TIP Report for the first time - as a Tier I country, of course. However, 2010 also marked a new low for Singapore, being the first - and only - time it has been placed in the Watch List. The report explained that the shift was based on quantifiable indicators, specifically noting the lack of labour trafficking prosecutions or convictions, and the low number (two) of sex trafficking convictions. The sudden attention being paid to the number of labour trafficking convictions is in line with the shift researchers have noted in the report's overall focus. However, also included in the report was a recommendation for Singapore to reduce demand for trafficking by enforcing existing laws and shutting down brothels evidence of the continued influence of abolitionism. ${ }^{85}$

Singapore's initial response to the 2010 report came from the Ministry of Foreign Affairs (MFA), who called the report "more a political issue than an objective study." 86 Subsequently, however, a full response was submitted with input from the MHA, the MOM and the Ministry of Community Development, Youth and Sports (MCYS) ${ }^{87}$ Later that year, Singapore formed its Inter-Agency Task Force on Trafficking in Persons (ITF), which is co-chaired by the MHA and the MOM and includes representatives from the Singapore Police Force (SPF), the MCYS, the MFA, the Checkpoints Authority, the Ministry of Health, the Ministry of Law, and the Attorney General's Chambers. ${ }^{88}$ Given previous government statements this move should be seen as a reaction to the Watch List placement, a reflection of both how seriously Singapore took its ranking and how willing it was to work towards improving it.

Their efforts proved successful. In 20I I, Singapore was taken off the Watch List, with specific praise given to the formation of the ITF, though the report continued to criticise Singapore for not taking steps to reduce demand. ${ }^{89}$ The ITF responded with its own report rebutting some of the statements in the TIP Report that year, including a statement that "the SPF conducts proactive enforcement for the purpose of reducing

83. Jacqueline BERMAN, "Left, the Right, and the Prostitute: The Making of U.S. Antitrafficking in Persons Policy" (2006) I 4:2 Tulane Journal of International and Comparative Law 269; Chuang, supra note 60; Gretchen SODERLUND, "Running from the Rescuers: New U.S. Crusades Against Sex Trafficking and the Rhetoric of Abolition" (2005) I7:3 NWSA Journal 64; Weitzer, supra note 64.

84. Frances P. BERNAT and Tatyana ZHILINA, "Trafficking in Humans: The TIP Report" (2OII) 5:6 Sociology Compass 452; Gallagher, "Improving the Effectiveness of Law", supra note 63.

85. US Department of State, 2009 Trafficking in Persons Report (Washington, DC: US Department of State, 2009) at 256-258; US Department of State, 20IO Trafficking in Persons Report (Washington, DC: US Department of State, 2010) at 292-294.

86. WEE Keat Leong, "Human Trafficking Watch - Singapore Ranks Alongside Afghanistan" Transitioning. org (I6 June 20I0), online: Transitioning.Org <http://www.transitioning.org/20Io/o6/I6/humantrafficking-watch-singapore-ranks-alongside-afghanistan/ $>$.

87. Singapore Inter-Agency Taskforce on Trafficking in Persons, Singapore Inter-Agency Taskforce's Detailed Response to the 20I I US State Department's Trafficking In Persons Report (Singapore, 20II) [Singapore Inter-Agency Taskforce on Trafficking in Persons, Detailed Response].

88. Pau Khan Khup HANGZO and Alistair D.B. COOK, Trafficking in Persons: Singapore's Evolving Responses (Singapore: RSIS Centre for Non-Traditional Security, April 201 2).

89. US Department of State, 201 I Trafficking in Persons Report (Washington, DC: US Department of State, 2OII) at 3I9-323 [US Department of State, 2OII TIP Report]. 
demand for commercial sexual services. In 2010, SPF conducted 3,608 anticommercial sex operations which led to the arrest of 94 commercial sex agents or 'pimps'." 90 In its own press statement that year, the MFA went further and claimed that in Singapore, in contrast to the United States, all sex workers are considered prima facie to be victims of human trafficking. ${ }^{9 \mathrm{I}}$ These statements mark a clear break with Wong Kan Seng's earlier tone, and suggest that in response to American pressure Singapore has begun both employing the rhetoric of the abolitionist movement as well as adopting some of its favoured tactics.

Singapore remained in Tier 2 in 201 2 , despite the release the previous year earlier of a National Plan of Action ${ }^{92}$ for the ITF which has won cautious praise from NGOs and researchers normally critical of the Singapore's record on human trafficking. ${ }^{93}$ The report that year criticised the inadequate penalties given to sex traffickers and, once more, the lack of effort to reduce demand for commercial sex. ${ }^{94}$ In 2013 , Singapore again remained in Tier 2 ; as with the previous three years, this is largely on account of issues related to labour trafficking. ${ }^{95}$ However, there was one item that had changed for the first time in the history of the report: Singapore, it reported, had at last made "limited efforts to reduce the demand for...commercial sex." 96 This praise was repeated in 20I 4 after another year of heavy raids, though Singapore continues to be placed in Tier $2 .{ }^{97}$

\section{Singapore's Policy Responses to the TIP Report}

The TIP Report's 2013 praise of Singapore's demand reduction efforts is almost certainly a result of the SPF's highly publicised raids of brothels and the DRAs. In 201 2 , the SPF conducted 3,567 raids on brothels, up from 2,643 raids the year before, and the ITF explicitly linked these raids to the fight against human trafficking. ${ }^{98}$ Given Singapore's historical tolerationist extra-legal regulatory system, its relatively recent

90. Singapore Inter-Agency Taskforce on Trafficking in Persons, Detailed Response, supra note 87.

91. Mustafa SHAFAWI, "US Human Trafficking Report 'Riddled with Inaccuracies" Channel News Asia (28 June 20II), online: Trafficking Monitor <http://trafficking-monitor.blogspot.com.au/20I I/o6/ushuman-trafficking-report-riddled.html $>$.

92. Singapore Inter-Agency Taskforce on Trafficking in Persons, National Plan of Action against Trafficking in Persons 20I2-20I5 (Singapore, 20I2).

93. Libby CLARKE, FDW Trafficking Research Report (Singapore: Humanitarian Organisation for Migration Economics, 20I 2); HOME, HOME's Response to TIP Report 20I 2: Singapore (Singapore: Humanitarian Organisation for Migration Economics, 20I2) [HOME, Home's Response]; Rachel CHHOA-HOWARD, "Singapore Launches National Plan of Action on Trafficking” RIGHTSWRITER (2I March 20I2), online: RIGHTSWRITER <http://rightswriter.wordpress.com/20I 2/03/2 I/singaporelaunches-national-plan-of-action-on-trafficking/ >; Caroline PARKES and Kathryn BAER, Statement on the Implementation of the National Plan of Action Against Trafficking in Persons (Singapore: The Trafficking Research Project, 20I2).

94. US Department of State, 2012 Trafficking in Persons Report (Washington, DC: US Department of State, 2OI2) at 3O8-3II.

95. US Department of State, 2013 TIP Report, supra note 62 at 326-329.

96. Ibid.

97. US Department of State, 20I4 Trafficking in Persons Report (Washington, DC: US Department of State, 20I4) [US Department of State, 2014 TIP Report].

98. Pei Shan HOE, "More Being Done to Fight Human Trafficking” Straits Times (30 June 20I3), online: Straits Times <http:/www.straitstimes.com/breaking-news/singapore/story/more-being-done-fighthuman-trafficking-20130630>. 
insistence that demand for sex work does not fuel human trafficking and its demonstrated responsiveness to the TIP Report, it is highly likely that these raids are largely in response to the continued critical language in the TIP Report regarding demand reduction. This conclusion is reinforced by the relatively restrained nature of civil society in Singapore: though the government claims to encourage civil society, this is limited to groups which can assist or compliment the government's own policy priorities, while groups that are critical of the government on sensitive issues can be censored or marginalised. ${ }^{99}$

The major civil society groups that are active in Singapore on human trafficking appear to unanimously reject abolitionism. AWARE (the Association of Women for Action and Research) is Singapore's earliest and most powerful feminist organisation. ${ }^{\text {I0० }}$ However, having rejected an attempted take-over by conservative Christian groups in $2009,{ }^{\text {IOI }}$ it currently follows a definition of human trafficking in line with the sex workers' rights movement. ${ }^{\text {IO2 }}$ HOME (the Humanitarian Organisation for Migration Economics) is the major anti-trafficking NGO in Singapore, and its founder was honoured for this work by the US State Department in 20I. ${ }^{\text {IO3 }}$ But HOME also only links sex work to human trafficking when it involves force, coercion, and debt bondage and is primarily concerned with labour trafficking. ${ }^{\text {IO4 }}$ HOME's own report praising the 2012 TIP Report notably says nothing about demand reduction. ${ }^{\text {IO5 }}$ And the Singapore-based Trafficking Research Project, which had previously used the content of the TIP Report to argue that Singapore was not taking sufficient action against human trafficking, writes that the 2012 Report "appears to be advocating that an appropriate strategy to counter sex trafficking is to reduce the demand for legal commercial sex. This is not a proven strategy to effectively end human trafficking." I06

Singapore's record of responsiveness to the TIP Report and the absence of a strong domestic abolitionist movement thus strongly suggest that its recent policy of raids on brothels and the DRAs is a response to the TIP Report's focus on demand reduction. However, this does not explain why the TIP Report was able to influence Singapore's public policy. It appears unlikely that Singapore is concerned about the economic consequences of the TIP Report. On the one hand, as a rich nation, Singapore is not

99. Stephan ORTMANN, "Policy Advocacy in a Competitive Authoritarian Regime The Growth of Civil Society and Agenda Setting in Singapore" (2OI2) 44:6 Administration and Society Supplement I 3 S; Terence LEE, "The Politics of Civil Society in Singapore" (2002) 26:I Asian Studies Review 97; Joel GWYNNE, "Slutwalk, Feminist Activism and the Foreign Body in Singapore" (2013) 43:I Journal of Contemporary Asia I73.

ıо०. Lenore LYONS, “The Limits of Feminist Political Intervention in Singapore” (2000) 30:I Journal of Contemporary Asia 67.

Ior. Terence CHONG, The AWARE Saga: Civil Society and Public Morality in Singapore (Singapore: NUS Press, 20I I); “Taken Unawares: Singapore's NGO Furore” The Economist (7 May 2009), online: The Economist <http://www.economist.com/node/I36I I 576>.

I02. AWARE, "Research and Advocacy: Projects: Ongoing" (9 August 20I4), online: AWARE <http://www. aware.org.sg/research-advocacy/projects/ongoing/ > .

I03. US Department of State, 201 I TIP Report, supra note 89 at 49.

I04. HOME, "The ıо Facts", online: HOME <http://www.home.org.sg/facts/index.html >.

I05. HOME, Home's Response, supra note 93.

I06. Caroline PARKES and Kathryn BAER, A Response to the United States Trafficking in Persons Report (2OI2) Specifically as It Relates to Singapore (Singapore: The Trafficking Research Project, 2OI2). 
reliant on US aid or assistance from multilateral institutions such as the IMF, so the financial impact of a Tier 3 placement is unlikely to be significant. On the other hand, Singapore and the US enjoy reasonably good relations, and Tier 3 placement has historically been reserved for American enemies such as Cuba, Iran, and North Korea. ${ }^{\text {I07 }}$ Though the report has in recent years been more willing to punish persistent non-compliers in Southeast Asia (Thailand and Malaysia were both placed in Tier 3 in the 20I4 report) these are cases of Watch List countries being automatically downgraded. ${ }^{\text {108 }} \mathrm{Had}$ it wanted to, Singapore likely could have followed Japan's example of persistently ranking in Tier 2 (where it has been for ten years as of 20I4) while doing nothing by way of demand reduction.

It is also unlikely that the government of Singapore has come to accept the doctrine that the very existence of its sex industry fuels the demand for human trafficking. This is because even American officials based in Singapore do not believe that there are any significant cases of human trafficking in Singapore's sex industry. ${ }^{\text {IO9 }}$ In private, the Singapore National Police and the MHA agree with this assessment. Nevertheless, they continue to conduct raids on establishments offering sexual services in response to pressure from the US State Department. ${ }^{\text {I } 0}$

The mostly likely reason, then, is that Singapore is responding to the reputational damage it has been incurring as a result the "naming and shaming" effect of continuous Tier 2 placement. ${ }^{\text {II I }}$ While this effect applies to all countries, Singapore in particular has long prided itself on its "brand" as communicated through international rankings. ${ }^{\text {II } 2}$ The TIP Report's influence, then, may derive from its ability to threaten this brand, and Singapore's policy makers may simply by looking to implement whatever policies might most easily improve their tier ranking. This position may not be entirely unreasonable - as a city-state whose economy is entirely reliant on international trade, damage to Singapore's reputation could have broader economic consequences. Nevertheless, this would, if accurate, suggest that these policy makers are allowing branding considerations to trump human rights concerns in their regulation of migrant sex work.

In this context, the use of raids is a particularly problematic development, since existing research suggest that not only are raids an ineffective strategy for reducing human trafficking, they can actually backfire in several critical ways. A report from the Sex Workers Project on the use of raids in the United States found that even when raids

\footnotetext{
I07. Tellingly, American allies in the Gulf such as Saudi Arabia and Qatar were categorised as Tier 3 in $200 \mathrm{I}$ and 2002 but got an upgrade in 2003 , the first year sanctions were actually enforced.

I08. US Department of State, 2014 TIP Report, supra note 97.

I09. See for example leaked versions of the cables from the US embassy in Singapore in 2006 and 2007 , see online: Cablegate <http://cablegatesearch.net/ > . See also Ko-lin CHIN and James O. FINCKENAUER, Selling Sex Overseas: Chinese Women and the Realities of Prostitution and Global Sex Trafficking (New York: NYU Press, 2OI2) at 2I3-2I4.

I Iо. Ibid.

II I. H. Richard FRIMAN, "Numbers and Certification: Assessing Foreign Compliance in Combating Narcotics and Human Trafficking" in Peter ANDREAS and Kelly M GREENHILL, eds., Sex, Drugs, and Body Counts: The Politics of Numbers in Global Crime and Conflict (Ithaca, N.Y.: Cornell University Press, 2010), 75 .

I I 2. Peter van HAM, “The Rise of the Brand State: The Postmodern Politics of Image and Reputation" (200I) 80:5 Foreign Affairs 2; Hangzo and Cook, supra note 88.
} 
locate victims of human trafficking, those victims are often not correctly identified and are instead charged with prostitution. Victims who are correctly identified can be traumatised by the raids and are unlikely to cooperate with the subsequent prosecutions of traffickers. Furthermore, victims have described situations where fear of law enforcement is part of what had kept them from leaving their situation earlier on their own, and statistically victims who willingly come forward make far better witnesses then those forced to testify after a raid. ${ }^{\text {II3 }}$

Some of these negative consequences are already visible in existing studies of migrant sex workers in Singapore. For example, the Vietnamese sex workers Lainez spoke to all claimed to have willingly and knowingly migrated to Singapore for the purpose of engaging in sex work. However, the migrants' greatest fear, which kept them voluntarily holed up in their tiny apartment all day, was getting caught by law enforcement. ${ }^{\text {II } 4}$ Another particularly striking case is that of the Thai sex workers employed in jungle brothels - a case which merited special mention in the TIP Report in 20I0. After speaking with individuals who had worked in these brothels, Yea found that it was the fear of police raids that kept migrants trapped in the jungle brothels rather than joining other Thai sex workers in more economically empowering and comfortable surroundings. ${ }^{\text {I } 5}$ For the moment, it appears that the SPF is only arresting pimps in these raids and that it is letting the sex workers go without checking their legal status in the country. ${ }^{\mathrm{II}}$ Nevertheless, it is clear from accounts like Yea's and Lainez's that these raids are contributing to a climate of mistrust and fear of the police, which in turn makes sex workers more vulnerable to exploitation.

\section{CONCLUSION}

The current trend for measures aimed at demand reduction in the sex industry thus appears to be a result of the influence of a transnational abolitionist movement. This situation has clear historical parallels: in the I920s, Singapore cracked down on various portions of its sex industry in order to satisfy an earlier transnational abolitionist movement. Unfortunately, these earlier policies resulted in some immediate negative consequences for the specific sex workers targeted, such as the Japanese sex workers who were repatriated to stigma and discrimination. It also had long term negative consequences for Singapore's regulation of the sex industry, culminating in the disastrous attempt to crack down on sex work as part of the anti-yellow culture campaign of 1959.

The extra-legal regulatory system Singapore has in place today for sex work is built on a historical understanding that abolitionism leads to failed policies. While it is possible to critique the State for an over-extension of surveillance and bio-power, these

\footnotetext{
I I3. Melissa DITMORE, The Use of Raids to Fight Trafficking in Persons (New York: Sex Workers Project, 2009); Empower, A Report by Empower Chiang Mai on the Human Rights Violations Women are Subjected to when "Rescued" by Anti-Trafficking Groups Who Employ Methods Using Deception, Force and Coercion (Thailand, 2003).

I 4. Supra note $5 \mathrm{I}$.

I I5. Yea, supra note 54 .

I 16. Chin and Finckenauer, supra note Io9 at 213-2I4.
} 
particular policies have nevertheless been effective at achieving their goals: MSSregistered sex workers have an STI infection rate of less than 5 percent, and, in private, even US officials are willing to admit that Singapore has a very low rate of human trafficking for sexual exploitation. However, as a result of sex worker stigma, antimigrant animus and heteronormativity, the registration system only includes a portion of sex workers, with those outside the system being more vulnerable to both disease and exploitation.

Some previous researchers have suggested that the successes of the DRAs and the MSS mean that these systems should be formally incorporated into the legal system, expanded to include presently excluded workers, and that migrant sex workers should be granted greater political rights - including a potential path to citizenship. ${ }^{\text {II }}$ However, the government of Singapore appears to feel that exposing the extra-legal system to the vagaries of democratic legislative proceedings risks blowing the whole thing up. Moreover, given the present level of anti-immigrant sentiment, any effort to extend greater rights to migrant sex workers would seem to be a political loser. This suggests that the best way for Singapore to improve the working conditions and safety of sex work would be to first work towards ending sex worker stigma. This would in turn allow the country to eventually have an open conversation about its extra-legal regulation of sex workers and perhaps formalise the system in legalisation.

Unfortunately, by embracing raids as a tool to fight human trafficking, Singapore is likely increasing sex worker stigma instead. Images on TV of sirens outside of KTVs and scantily clad women in handcuffs help perpetuate a popular conception of sex workers as criminal and immoral, even if the women in question are ultimately released without charges. Moreover, based on the available evidence, raids do not appear to be an effective tool for ending human trafficking for sexual exploitation, and may in fact lead to heightened rates of victimisation.

That said, as Singaporean NGOs have pointed out, the problem goes beyond simply the use of raids to the focus on demand reduction itself, since targeting the demand for commercial sex has not been proven to reduce human trafficking and has many demonstrable externalities. However, it is also unreasonable to suggest that Singapore simply ignore the report, because its status as a global city does mean that reputational damage could have negative economic outcomes. Fortunately, however, there are other ways Singapore could improve its tier rating: the 20I4 TIP Report has II recommendations, most of which are unrelated to policing or sex work. ${ }^{\text {I } 8}$ As such, if Singapore aims to improve its tier rating in the US TIP Report while also improving the health and safety of sex workers, it should aim to address other American concerns, particularly those related to labour trafficking, while avoiding the use of raids to signal a commitment to reducing the demand for sex work.

II7. See e.g. Wong, "Brothels, Pimps and Prostitutes", supra note 42.

I I 8. US Department of State, 20I4 TIP Report, supra note 97 at 342. 